doi: $10.2306 /$ scienceasia1513-1874.2013.39.278

\title{
IR analysis of borate glasses containing three alkali oxides
}

\author{
L. Balachander ${ }^{\mathrm{a}}$, G. Ramadevudu ${ }^{\mathrm{b}, *}$, Md. Shareefuddin ${ }^{\mathrm{a}}$, R. Sayanna ${ }^{\mathrm{c}}$, Y.C. Venudhar ${ }^{\mathrm{c}}$ \\ a Department of Physics, Nizam College (Autonomous), Osmania University, Hyderabad 500 001, India \\ b Department of Physics, Vasavi College of Engineering, Ibrahimbagh, Hyderabad 31, India \\ c Department of Physics, Osmania University, Hyderabad 500 007, India
}

*Corresponding author, e-mail: dr.ramdev@gmail.com

Received 4 Sep 2012

Accepted 28 Dec 2012

\begin{abstract}
FTIR investigations on borate glasses containing three alkali oxides, $x \mathrm{Li}_{2} \mathrm{O} \cdot x \mathrm{Na}_{2} \mathrm{O} \cdot x \mathrm{~K}_{2} \mathrm{O} \cdot(50-3 x) \mathrm{PbO}$ . $50 \mathrm{~B}_{2} \mathrm{O}_{3}(x=8,10,12,14$, and $16 \mathrm{~mol} \%), 10 \mathrm{Li}_{2} \mathrm{O} \cdot 10 \mathrm{Na}_{2} \mathrm{O} \cdot 10 \mathrm{~K}_{2} \mathrm{O} \cdot y \mathrm{PbO} \cdot(70-y) \mathrm{B}_{2} \mathrm{O}_{3}(y=25,30,35,40$, and $50 \mathrm{~mol} \%)$, and $x \mathrm{Li}_{2} \mathrm{O} \cdot x \mathrm{Na}_{2} \mathrm{O} \cdot x \mathrm{~K}_{2} \mathrm{O} \cdot(50-3 x) \mathrm{Bi}_{2} \mathrm{O}_{3} \cdot 50 \mathrm{~B}_{2} \mathrm{O}_{3}(x=8,10,12,14$, and $16 \mathrm{~mol} \%)$ are reported. The present glasses contain mainly $\mathrm{BO}_{3}$ and $\mathrm{BO}_{4}$ structural units. The presence of fingerprints of both $\mathrm{BiO}_{3}$ and $\mathrm{BiO}_{6}$ structural units in bismuth alkali borate glasses was confirmed. The presence of varied types like di, tetra, penta, and ortho borate groups are confirmed in the glass matrix. Glasses with low $\mathrm{PbO}$ content contained more $\mathrm{BO}_{3}$ units than $\mathrm{BO}_{4}$ units.
\end{abstract}

KEYWORDS: glass formers, glass modifier, borate groups, non-bridging oxygen atoms

\section{INTRODUCTION}

Alkali borate glasses have been studied for various technical and industrial applications. The insulating property of borate glasses turns into a semiconducting or electronic or ion conducting nature when metal oxides such as alkali and alkaline earth oxides are added to them. Alkali borate glass systems are good candidates for ion conduction and suitable for the fabrication of solid state batteries. Borate glasses with heavy metal ions such as $\mathrm{Bi}, \mathrm{Pb}, \mathrm{Zn}$ etc. exhibit good nonlinear optical properties ${ }^{1}$.

Borate glasses containing lead oxide have several applications including radiation shields, optical, and thermal properties ${ }^{2-4}$. Similarly bismuth containing oxide glasses have advantages such as host materials for lasers, long IR cut-off, glass ceramics, memory, and switching devices ${ }^{5,6}$. PbO plays a role of glass former at higher composition while it exhibits glass modifier action at low concentration in the glass ${ }^{3}$. High content $\mathrm{PbO}$ glasses contain mixture of both $\mathrm{PbO}_{3}$ and $\mathrm{PbO}_{4}$ structural units ${ }^{7}$. Some authors proposed that $\mathrm{Bi}_{2} \mathrm{O}_{3}$ glasses contain both $\mathrm{BiO}_{6}$ and $\mathrm{BiO}_{3}$ groups ${ }^{4,8}$.

Fourier transform infrared (FTIR) technique is one of the most sought spectroscopic investigations to probe the structural units present in the glass matrix. The structure of borate glass not only depends on the glass forming oxides, but also on the glass modifier oxides and dopant salts present in the glass composition. The present paper reports structural investigations on borates glasses containing three alkali oxides using FTIR technique. We present the action of $\mathrm{PbO}$ when the content of alkali oxides remains the same and when it varies in borate glass structure. The paper also reports the structural groups of $\mathrm{Bi}_{2} \mathrm{O}_{3}$ when the content of alkali oxides remains constant in the borate glass network.

\section{EXPERIMENTAL}

Glass systems $x \mathrm{Li}_{2} \mathrm{O} \cdot x \mathrm{Na}_{2} \mathrm{O} \cdot x \mathrm{~K}_{2} \mathrm{O} \cdot(50-3 x) \mathrm{PbO}$ $.50 \mathrm{~B}_{2} \mathrm{O}_{3}(x=8,10,12,14$, and $16 \mathrm{~mol} \%), 10 \mathrm{Li}_{2} \mathrm{O}$ - $10 \mathrm{Na}_{2} \mathrm{O} \cdot 10 \mathrm{~K}_{2} \mathrm{O} \cdot y \mathrm{PbO} \cdot(70-y) \mathrm{B}_{2} \mathrm{O}_{3}(y=25$, $30,35,40$, and $50 \mathrm{~mol} \%$ ), and $x \mathrm{Li}_{2} \mathrm{O} \cdot x \mathrm{Na}_{2} \mathrm{O}$. $x \mathrm{~K}_{2} \mathrm{O} \cdot(50-3 x) \mathrm{Bi}_{2} \mathrm{O}_{3} \cdot 50 \mathrm{~B}_{2} \mathrm{O}_{3}(x=8,10,12$, 14 , and $16 \mathrm{~mol} \%$ ) were prepared by conventional melt quenching technique. The starting chemicals of AnalaR grade, namely lithium carbonate $\left(\mathrm{Li}_{2} \mathrm{CO}_{3}\right)$, sodium carbonate $\left(\mathrm{Na}_{2} \mathrm{CO}_{3}\right)$, potassium carbonate $\left(\mathrm{K}_{2} \mathrm{CO}_{3}\right)$, boric acid $\left(\mathrm{H}_{3} \mathrm{BO}_{3}\right)$, bismuth oxide $\left(\mathrm{Bi}_{2} \mathrm{O}_{3}\right)$, and lead monoxide $(\mathrm{PbO})$ were weighed to get the required composition in mole percentage. After thorough grinding, these materials were transferred into a porcelain crucible and melted in an electric furnace at $1000{ }^{\circ} \mathrm{C}$ for about $30 \mathrm{~min}$. For homogeneity of glass samples, the melt was frequently stirred. The melt was then quenched rapidly in air onto a stainless steel plate maintained at $373 \mathrm{~K}$ and kept at that temperature to relieve mechanical strains in the glass until the stainless steel plate returned to room temperature in ambient conditions. The glass samples thus prepared are clear with no air bubbles. The compositions of the present glass samples were given Table 1 . 


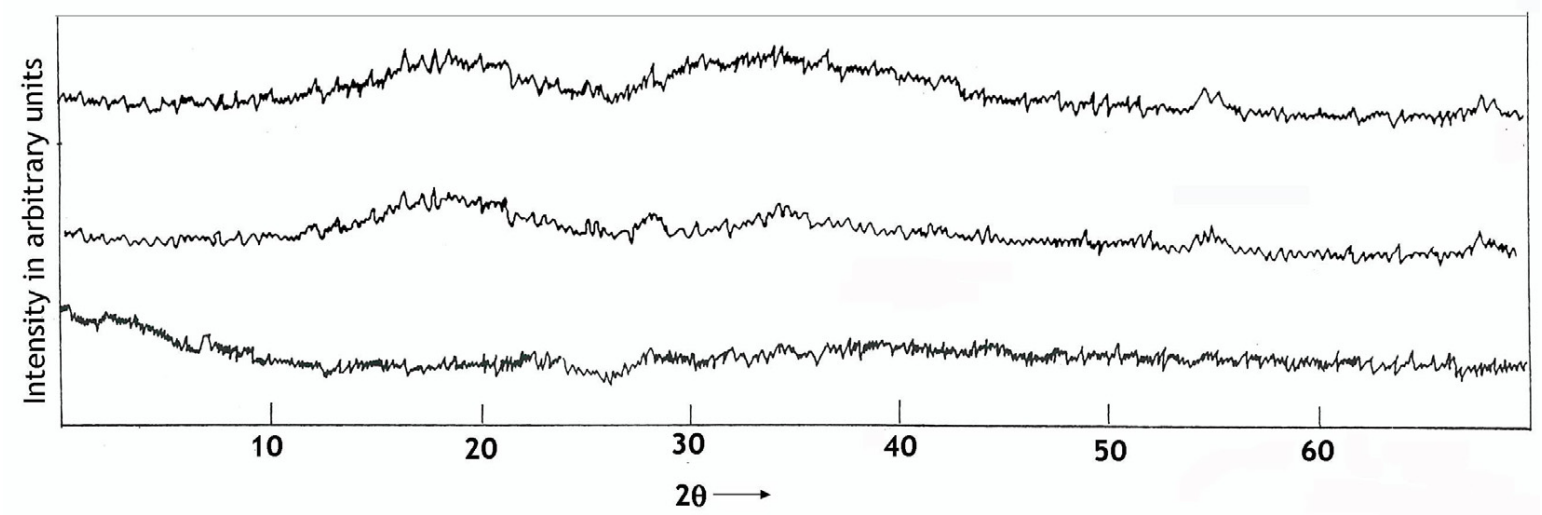

Fig. 1 Powder X-ray diffractograms of some glass samples.

Table 1 Glass compositions.

\begin{tabular}{|c|c|}
\hline Glass & Composition \\
\hline LP1 & $8 \mathrm{Li}_{2} \mathrm{O} \cdot 8 \mathrm{Na}_{2} \mathrm{O} \cdot 8 \mathrm{~K}_{2} \mathrm{O} \cdot 26 \mathrm{PbO} \cdot 50 \mathrm{~B}_{2} \mathrm{O}_{3}$ \\
\hline LP2 & $10 \mathrm{Li}_{2} \mathrm{O} \cdot 10 \mathrm{Na}_{2} \mathrm{O} \cdot 10 \mathrm{~K}_{2} \mathrm{O} \cdot 20 \mathrm{PbO} \cdot 50 \mathrm{~B}_{2} \mathrm{O}_{3}$ \\
\hline LP3 & $12 \mathrm{Li}_{2} \mathrm{O} \cdot 12 \mathrm{Na}_{2} \mathrm{O} \cdot 12 \mathrm{~K}_{2} \mathrm{O} \cdot 14 \mathrm{PbO} \cdot 50 \mathrm{~B}_{2} \mathrm{O}_{3}$ \\
\hline LP4 & $14 \mathrm{Li}_{2} \mathrm{O} \cdot 14 \mathrm{Na}_{2} \mathrm{O} \cdot 14 \mathrm{~K}_{2} \mathrm{O} \cdot 8 \mathrm{PbO} \cdot 50 \mathrm{~B}_{2} \mathrm{O}_{3}$ \\
\hline LP5 & $16 \mathrm{Li}_{2} \mathrm{O} \cdot 16 \mathrm{Na}_{2} \mathrm{O} \cdot 16 \mathrm{~K}_{2} \mathrm{O} \cdot 2 \mathrm{PbO} \cdot 50 \mathrm{~B}_{2} \mathrm{O}_{3}$ \\
\hline HP1 & $10 \mathrm{Li}_{2} \mathrm{O} \cdot 10 \mathrm{Na}_{2} \mathrm{O} \cdot 10 \mathrm{~K}_{2} \mathrm{O} \cdot 25 \mathrm{PbO} \cdot 45 \mathrm{~B}_{2} \mathrm{O}_{3}$ \\
\hline HP2 & $10 \mathrm{Li}_{2} \mathrm{O} \cdot 10 \mathrm{Na}_{2} \mathrm{O} \cdot 10 \mathrm{~K}_{2} \mathrm{O} \cdot 30 \mathrm{PbO} \cdot 40 \mathrm{~B}_{2} \mathrm{O}_{3}$ \\
\hline HP3 & $10 \mathrm{Li}_{2} \mathrm{O} \cdot 10 \mathrm{Na}_{2} \mathrm{O} \cdot 10 \mathrm{~K}_{2} \mathrm{O} \cdot 35 \mathrm{PbO} \cdot 35 \mathrm{~B}_{2} \mathrm{O}_{3}$ \\
\hline HP4 & $10 \mathrm{Li}_{2} \mathrm{O} \cdot 10 \mathrm{Na}_{2} \mathrm{O} \cdot 10 \mathrm{~K}_{2} \mathrm{O} \cdot 40 \mathrm{PbO} \cdot 30 \mathrm{~B}_{2} \mathrm{O}_{3}$ \\
\hline HP5 & $10 \mathrm{Li}_{2} \mathrm{O} \cdot 10 \mathrm{Na}_{2} \mathrm{O} \cdot 10 \mathrm{~K}_{2} \mathrm{O} \cdot 45 \mathrm{PbO} \cdot 25 \mathrm{~B}_{2} \mathrm{O}_{3}$ \\
\hline HP6 & $10 \mathrm{Li}_{2} \mathrm{O} \cdot 10 \mathrm{Na}_{2} \mathrm{O} \cdot 10 \mathrm{~K}_{2} \mathrm{O} \cdot 50 \mathrm{PbO} \cdot 20 \mathrm{~B}_{2} \mathrm{O}_{3}$ \\
\hline BB1 & $8 \mathrm{Li}_{2} \mathrm{O} \cdot 8 \mathrm{Na}_{2} \mathrm{O} \cdot 8 \mathrm{~K}_{2} \mathrm{O} \cdot 26 \mathrm{Bi}_{2} \mathrm{O}_{3} \cdot 50 \mathrm{~B}_{2} \mathrm{O}_{3}$ \\
\hline BB2 & $10 \mathrm{Li}_{2} \mathrm{O} \cdot 10 \mathrm{Na}_{2} \mathrm{O} \cdot 10 \mathrm{~K}_{2} \mathrm{O} \cdot 20 \mathrm{Bi}_{2} \mathrm{O}_{3} \cdot 50 \mathrm{~B}_{2} \mathrm{O}_{3}$ \\
\hline BB3 & $12 \mathrm{Li}_{2} \mathrm{O} \cdot 12 \mathrm{Na}_{2} \mathrm{O} \cdot 12 \mathrm{~K}_{2} \mathrm{O} \cdot 14 \mathrm{Bi}_{2} \mathrm{O}_{3} \cdot 50 \mathrm{~B}_{2} \mathrm{O}_{3}$ \\
\hline BB4 & $14 \mathrm{Li}_{2} \mathrm{O} \cdot 14 \mathrm{Na}_{2} \mathrm{O} \cdot 14 \mathrm{~K}_{2} \mathrm{O} \cdot 8 \mathrm{Bi}_{2} \mathrm{O}_{3} \cdot 50 \mathrm{~B}_{2} \mathrm{O}_{3}$ \\
\hline BB5 & $16 \mathrm{Li}_{2} \mathrm{O} \cdot 16 \mathrm{Na}_{2} \mathrm{O} \cdot 16 \mathrm{~K}_{2} \mathrm{O} \cdot 2 \mathrm{Bi}_{2} \mathrm{O}_{3} \cdot 50 \mathrm{~B}_{2} \mathrm{O}_{3}$ \\
\hline
\end{tabular}

All the glass samples were characterized ( $2 \theta$ values between 0 and $80^{\circ}$ ) by Siemens D-5000 model $\mathrm{X}$-ray diffractometer to check their amorphous nature. The powder X-ray diffractograms of few glass samples are shown in Fig. 1. The FTIR vibration spectra of the present glasses were recorded at room temperature using $\mathrm{KBr}$ pellet technique in the wavenumber range $400-4000 \mathrm{~cm}^{-1}$ using Perkin-Elmer 467 spectrometer which has a resolution of $1 \mathrm{~cm}^{-1}$.

\section{RESULTS AND DISCUSSION}

The amorphous nature of the glass samples was confirmed from the peak free X-ray diffractograms (Fig. 1). Fig. 2 shows the FTIR spectra of glass samples. The peaks corresponding to the infrared bands observed in these glasses are given in Table 2 . The main active vibrational modes of the borate

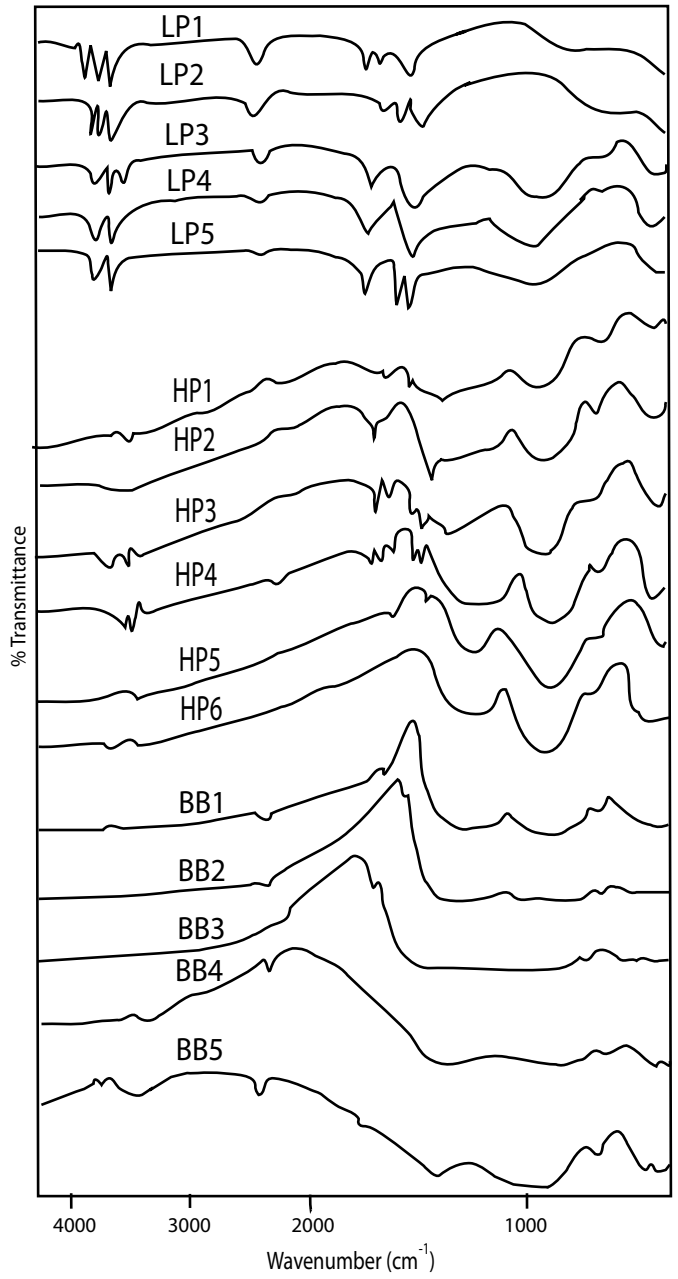

Fig. 2 FTIR spectra of present glass samples.

network observed in the present glasses are in three infrared groups $\left(1200-1600 \mathrm{~cm}^{-1}, 800-1200 \mathrm{~cm}^{-1}\right.$, and around $\left.700 \mathrm{~cm}^{-1}\right)$ are similar to the values re- 
Table 2 Infrared absorption band positions of LP, HP, and BB glass series.

\begin{tabular}{lcccccc}
\hline Glass & \multicolumn{5}{c}{ IR band positions in wavenumber $\left(\mathrm{cm}^{-1}\right)$} \\
\hline LP1 & 475 & 667 & - & 1554 & 1613 & 1648 \\
LP2 & 470 & 726 & - & 1506 & 1615 & 1694 \\
LP3 & 473 & 761 & - & 1540 & & 1684 \\
LP4 & 468 & 726 & 996 & 1506 & & 1684 \\
LP5 & 473 & 738 & 1008 & 1507 & 1615 & 1684 \\
HP1 & 472 & 726 & 1008 & 1388 & 1506 & 1684 \\
HP2 & 473 & 726 & 961 & 1231 & 1507 & 1684 \\
HP3 & 473 & 720 & 972 & 1396 & 1506 & 1684 \\
HP4 & 479 & 726 & 944 & 1255 & 1508 & 1684 \\
HP5 & 473 & 720 & 956 & 1301 & 1508 & 1684 \\
HP6 & 473 & 726 & 948 & 1273 & 1508 & \\
BB1 & 497 & 544 & 714 & 954 & 1320 & 1649 \\
BB 2 & 473 & 520 & 726 & 1026 & 1372 & 1560 \\
BB 3 & 462 & 515 & 720 & 979 & 1407 & 1654 \\
BB 4 & 462 & 509 & 726 & 981 & 1407 & 1470 \\
BB 5 & 479 & 515 & 726 & 1012 & 1425 & 1713 \\
\hline
\end{tabular}

ported in the literature ${ }^{9}$. In pure $\mathrm{B}_{2} \mathrm{O}_{3}$ glass, the IR band at $806 \mathrm{~cm}^{-1}$ corresponding to characteristic of boroxol ring was not observed in all the present glass samples. The broad composite bands extending in the near infrared region $3200-3800 \mathrm{~cm}^{-1}$ are due to hydroxyl or water or B-OH groups present in the samples. The presence of these hydroxyl groups or water groups could be attributed to the $(\mathrm{KBr}$ technique) experimental procedure and may also arise due to the presence of water in $\mathrm{H}_{3} \mathrm{BO}_{3}$. IR band assignments are presented in Tables 3-5.

The intensity of the IR peak $\sim 2350 \mathrm{~cm}^{-1}$ decreased with increasing alkali oxide content and decreased with $\mathrm{PbO}$ content in the glass system $x \mathrm{Li}_{2} \mathrm{O}$ $\cdot x \mathrm{Na}_{2} \mathrm{O} \cdot x \mathrm{~K}_{2} \mathrm{O} \cdot(50-3 x) \mathrm{PbO} \cdot 50 \mathrm{~B}_{2} \mathrm{O}_{3}(x=8$, $10,12,14$, and $16 \mathrm{~mol} \%$ ). The broadening of peaks between 600 and $1000 \mathrm{~cm}^{-1}$ was also observed in these glasses.

With increasing $\mathrm{PbO}$ content in $10 \mathrm{Li}_{2} \mathrm{O} \cdot 10 \mathrm{Na}_{2} \mathrm{O}$ $\cdot 10 \mathrm{~K}_{2} \mathrm{O} \cdot y \mathrm{PbO} \cdot(70-y) \mathrm{B}_{2} \mathrm{O}_{3}(y=25,30,35$, 40,45 , and $50 \mathrm{~mol} \%$ ) glass system, broadening of peaks was observed. The intensity of the peak around $726 \mathrm{~cm}^{-1}$ was decreased with increasing $\mathrm{PbO}$ content in the glass matrix. With increase in $\mathrm{PbO}$ content, the positions of peaks between 1000 and $948 \mathrm{~cm}^{-1}$ were shifted to lower wavenumbers in this system of glasses.

In the glass system $x \mathrm{Li}_{2} \mathrm{O} \cdot x \mathrm{Na}_{2} \mathrm{O} \cdot x \mathrm{~K}_{2} \mathrm{O}$. $(50-3 x) \mathrm{Bi}_{2} \mathrm{O}_{3} \cdot 50 \mathrm{~B}_{2} \mathrm{O}_{3}$, the peak intensity around $700 \mathrm{~cm}^{-1}$ has grown. Bands around $540 \mathrm{~cm}^{-1}$ were shifted to lower wavenumbers while the peaks around
Table 3 IR band assignments for the glass samples $x \mathrm{Li}_{2} \mathrm{O}$ $\cdot x \mathrm{Na}_{2} \mathrm{O} \cdot x \mathrm{~K}_{2} \mathrm{O} \cdot(50-x) \mathrm{PbO} \cdot 50 \mathrm{~B}_{2} \mathrm{O}_{3}$.

\begin{tabular}{|c|c|}
\hline $\begin{array}{l}\text { Wavenumber } \\
\qquad\left(\mathrm{cm}^{-1}\right)\end{array}$ & IR band assignments \\
\hline$\sim 470$ & $\mathrm{~Pb}-\mathrm{O}$ bond \\
\hline & $\mathrm{O}-\mathrm{B}-\mathrm{O}$ bond bending vibrations \\
\hline$\sim 726$ & $\begin{array}{l}\mathrm{B}-\mathrm{O}-\mathrm{B} \text { linkages bending and isolated } \\
\mathrm{BO}_{3}^{3-} \text { groups }\end{array}$ \\
\hline$\sim 1000$ & $\begin{array}{l}\mathrm{B}-\mathrm{O} \text { bonds stretching vibrations in }\left[\mathrm{BO}_{4}\right] \\
\text { units from diborate groups }\end{array}$ \\
\hline $1230-1270$ & $\begin{array}{l}\text { Asymmetric stretching vibrations of } \mathrm{B}-\mathrm{O} \\
\text { bonds from pyro and ortho borate groups in } \\
{\left[\mathrm{BO}_{3}\right] \text { units }}\end{array}$ \\
\hline 1300 & Vibrations of boron oxygen rings \\
\hline$\sim 1506$ & $\begin{array}{l}\mathrm{B}-\mathrm{O}^{-} \text {bond stretching in }\left[\mathrm{BO}_{3}\right] \text { units due to } \\
\text { varied groups }\end{array}$ \\
\hline$\sim 1684$ & Crystal water with $\mathrm{H}-\mathrm{O}-\mathrm{H}$ bending mode \\
\hline
\end{tabular}

Table 4 IR band assignments for the glass samples $10 \mathrm{Li}_{2} \mathrm{O}$ $\cdot 10 \mathrm{Na}_{2} \mathrm{O} \cdot 10 \mathrm{~K}_{2} \mathrm{O} \cdot y \mathrm{PbO} \cdot(70-y) \mathrm{B}_{2} \mathrm{O}_{3}$.

\begin{tabular}{rl}
$\begin{array}{r}\text { Wavenumber } \\
\left(\mathrm{cm}^{-1}\right)\end{array}$ & IR band assignments \\
\hline 470 & $\begin{array}{l}\mathrm{Pb}-\mathrm{O} \text { bond vibrations } \\
\mathrm{O}-\mathrm{B}-\mathrm{O} \text { bond bending vibrations }\end{array}$ \\
$\sim 760$ & $\mathrm{~B}-\mathrm{O}-\mathrm{B}$ linkages bending in borate network \\
$\sim 1000$ & $\begin{array}{l}\mathrm{B}-\mathrm{O} \text { bonds stretching vibrations in }\left[\mathrm{BO}_{4}\right] \\
\text { units from diborate groups }\end{array}$ \\
$\sim 1200-1237$ & $\begin{array}{l}\text { Asymmetric stretching vibrations of } \mathrm{B}-\mathrm{O} \\
\text { bonds from pyro and ortho borate groups in } \\
{\left[\mathrm{BO}_{3}\right] \text { units }}\end{array}$ \\
$\sim 1506-1554$ & $\begin{array}{l}\mathrm{B}-\mathrm{O}^{-} \text {bond stretching in }\left[\mathrm{BO}_{3}\right] \text { units due to } \\
\text { varied groups }\end{array}$ \\
$\sim 1613-1684$ & Crystal water with $\mathrm{H}-\mathrm{O}-\mathrm{H}_{\text {bending mode }}$ \\
\hline
\end{tabular}

$1300-1425 \mathrm{~cm}^{-1}$ were shifted to higher wavenumbers. The weak bands around $1613-1684 \mathrm{~cm}^{-1}$ indicates existence of crystal water with $\mathrm{H}-\mathrm{O}-\mathrm{H}$ bending mode in the samples ${ }^{10}$.

The general identification of finger print IR bands in borate glasses in the group $1200-1600 \mathrm{~cm}^{-1}$ occur due to the asymmetric stretching relaxation of the B$\mathrm{O}$ bond of trigonal $\mathrm{BO}_{3}$ units. The peak positions that lie between 800 and $1200 \mathrm{~cm}^{-1}$ are attributed to the $\mathrm{B}-\mathrm{O}$ bond stretching of the tetrahedral $\mathrm{BO}_{4}$ units and the bands around $700 \mathrm{~cm}^{-1}$ are due to the bending $\mathrm{B}$ O-B linkages in the borate networks ${ }^{11,12}$. IR peaks between 2343 and $2367 \mathrm{~cm}^{-1}$ are attributed to the presence of $-\mathrm{OH}$ group in the glasses ${ }^{13,14}$.

In the glass system $x \mathrm{Li}_{2} \mathrm{O} \cdot x \mathrm{Na}_{2} \mathrm{O} \cdot x \mathrm{~K}_{2} \mathrm{O}$ . $(50-3 x) \mathrm{PbO} \cdot 50 \mathrm{~B}_{2} \mathrm{O}_{3}$ the infrared transmission bands are centred at 470,700,100,1200,1510, and $1684 \mathrm{~cm}^{-1}$. The band at $470 \mathrm{~cm}^{-1}$ corresponds to 
Table 5 IR band assignments for the glass samples $x \mathrm{Li}_{2} \mathrm{O}$ $\cdot x \mathrm{Na}_{2} \mathrm{O} \cdot x \mathrm{~K}_{2} \mathrm{O} \cdot(50-3 x) \mathrm{Bi}_{2} \mathrm{O}_{3} \cdot 50 \mathrm{~B}_{2} \mathrm{O}_{3}$.

Wavenumber IR band assignments

$\left(\mathrm{cm}^{-1}\right)$

$\sim 400-600 \mathrm{Bi}-\mathrm{O}-\mathrm{Bi}$ and $\mathrm{Bi}-\mathrm{O}$ in $\mathrm{BiO}_{6}$ octahedral

$\sim 470$ Total symmetric bending vibrations of $\mathrm{BiO}_{3}$ units

$\sim 520 \mathrm{Bi}-\mathrm{O}$ bonds in $\mathrm{BiO}_{6}$ units

$\sim 540$ Doubly degenerating stretching vibrations of $\mathrm{BiO}_{3}$ units

$\sim 726 \mathrm{~B}-\mathrm{O}-\mathrm{B}$ linkages

$\sim 950-980$ Stretching vibrations of $\mathrm{B}-\varnothing$ bonds in $\mathrm{B} \varnothing_{4}$ units from tri, tetra, and penta borate groups

1176-1500 B-O stretching vibrations of trigonal $\mathrm{BO}_{3}$ units only

$\sim 1320-1470 \quad \mathrm{~B}-\mathrm{O}$ symmetric stretching vibrations of varied borate groups in $\mathrm{BO}_{3}$ units

$\mathrm{B}-\mathrm{O}^{-}$symmetric stretching vibrations of varied borate groups in $\mathrm{BO}_{2} \mathrm{O}^{-}$

the overlapping of $\mathrm{O}-\mathrm{B}-\mathrm{O}$ bond bending vibrations and $\mathrm{Pb}-\mathrm{O}$ bond vibration ${ }^{6}$. The weak bands around $1000 \mathrm{~cm}^{-1}$ indicate $\mathrm{B}-\mathrm{O}$ bonds stretching vibrations in $\mathrm{BO}_{4}$ units from diborate groups. Asymmetric vibrations of $\mathrm{B}-\mathrm{O}$ bonds from pyro and ortho borate groups in $\mathrm{BO}_{3}$ trigonal units are confirmed from the peaks in the range $1200-1554 \mathrm{~cm}^{-1}$.

In general, it was observed that the alkali oxides in borate glasses form di, tetra, pyro, penta borate groups. It was reported in the literature that in lead borate glasses with low $\mathrm{PbO}$ content (less than $20 \mathrm{~mol} \%$ ), the $\mathrm{Pb}-\mathrm{O}$ bond is ionic and $\mathrm{Pb}^{2+}$ acts as modifier. As the $\mathrm{PbO}$ content in the present glass (Bseries) is less, an increase in $x$ mol\%, decreases the $\mathrm{PbO}$ content in the glass composition, and as a result these glasses contain more $\mathrm{BO}_{3}$ trigonal units rather than $\mathrm{BO}_{4}$ units. Lead borate glasses show similar IR absorption spectra as that of alkali and alkaline earth borate glasses ${ }^{12,15,16}$. Oxides such as $\mathrm{PbO}$, $\mathrm{Bi}_{2} \mathrm{O}_{3}$ etc play glass network former/modifier role in the borate glass matrix and enhance the stability of the borate glasses. $\mathrm{PbO}$ modifies $\mathrm{B}_{2} \mathrm{O}_{3}$ back bone structure by forming $\mathrm{BO}_{3}$ or $\mathrm{BO}_{4}$ tetrahedral structural units in the glass matrix. Similarly $\mathrm{Bi}_{2} \mathrm{O}_{3}$, well known glass network former, forms $\mathrm{BiO}_{3}$ pyramidal and $\mathrm{BiO}_{6}$ octahedral units in the glass 16,17 .

The broadening of peaks between 600 and $1000 \mathrm{~cm}^{-1}$ in low lead content LP glass series, i.e., $x \mathrm{Li}_{2} \mathrm{O} \cdot x \mathrm{Na}_{2} \mathrm{O} \cdot x \mathrm{~K}_{2} \mathrm{O} \cdot(50-3 x) \mathrm{PbO} \cdot 50 \mathrm{~B}_{2} \mathrm{O}_{3}$ $(x=8,10,12,14$, and $16 \mathrm{~mol} \%)$ with increase in alkali oxide content could be assigned to the modifier action and formation of non-bridging oxygen atoms
(NBOs). The decreasing $\mathrm{PbO}$ content is favourable to form $\mathrm{BO}_{3}$ units rather than $\mathrm{BO}_{4}$ units. The assignment of IR peaks to various vibrational frequencies in the present glass samples indicates that the glass matrix consists of variable borate groups belongs to $\mathrm{BO}_{3}$ units. Hence, these glasses are rich in $\mathrm{BO}_{3}$ units.

In contrast to the above LP glasses, HP series glasses, i.e., $10 \mathrm{Li}_{2} \mathrm{O} \cdot 10 \mathrm{Na}_{2} \mathrm{O} \cdot 10 \mathrm{~K}_{2} \mathrm{O} \cdot x \mathrm{PbO}$. $(70-x) \mathrm{B}_{2} \mathrm{O}_{3}$ are rich in lead content $(\geqslant 30 \mathrm{~mol} \%)$. The infrared peak centred around $470 \mathrm{~cm}^{-1}$ is a sign of $\mathrm{Pb}-\mathrm{O}$ bond vibrations present in $\mathrm{HP}$ series glass samples (Fig. 2 and Table 2). The peak around $726 \mathrm{~cm}^{-1}$ corresponds to vibrations of various borate segments. $948-1008 \mathrm{~cm}^{-1}$ bands can be attributed to $\mathrm{B}-\mathrm{O}$ bonds stretching vibrations of $\mathrm{BO}_{4}$ units from diborate groups ${ }^{6,16}$. Asymmetric stretching vibrations of B-O bonds from pyro and ortho borate groups in $\mathrm{BO}_{3}$ trigonal units are established with the presence of peaks between 1200 and $1554 \mathrm{~cm}^{-1}$. Thus HP series glasses contain both $\mathrm{BO}_{3}$ trigonal and $\mathrm{BO}_{4}$ tetrahedral units. As the $\mathrm{PbO}$ content increases in the glass, some of the $\mathrm{BO}_{3}$ trigonal units might have converted into $\mathrm{BO}_{4}$ tetrahedral units and non-bridging oxygen atoms might have formed.

The broadening of bands around $726 \mathrm{~cm}^{-1}$ with increasing $\mathrm{PbO}$ content in $10 \mathrm{Li}_{2} \mathrm{O} \cdot 10 \mathrm{Na}_{2} \mathrm{O} \cdot 10 \mathrm{~K}_{2} \mathrm{O}$ - $y \mathrm{PbO} \cdot(70-y) \mathrm{B}_{2} \mathrm{O}_{3}(y=25,30,35,40,45$, and $50 \mathrm{~mol} \%$ ) might be due to the increasing role of $\mathrm{PbO}$ as glass network former rather than glass network modifier. As the alkali content remains constant the increase in $\mathrm{PbO}$ content, IR band positions between 1000 and $948 \mathrm{~cm}^{-1}$ were shifted to lower wavenumbers and this could be attributed to the formation $\mathrm{BO}_{4}$ units at the expense of $\mathrm{BO}_{3}$ units.

Both LP and HP glasses contain bands between 470 and $497 \mathrm{~cm}^{-1}$. The bands arise due to the presence of $\mathrm{Pb}^{2+}$ or $\mathrm{Pb}-\mathrm{O}$ vibrations. Similarly bands around $1300 \mathrm{~cm}^{-1}$ correspond to vibration of boron oxygen rings 18,19 .

The infrared peaks below $610 \mathrm{~cm}^{-1}$ in $x \mathrm{Li}_{2} \mathrm{O}$. $x \mathrm{Na}_{2} \mathrm{O} \cdot x \mathrm{~K}_{2} \mathrm{O} \cdot(50-3 x) \mathrm{Bi}_{2} \mathrm{O}_{3} \cdot 50 \mathrm{~B}_{2} \mathrm{O}_{3}$, i.e., in $\mathrm{BB}$ series of glass samples arise due to cationic vibrations in the network and various modes of $\mathrm{Bi}-\mathrm{O}$ vibrations in $\mathrm{BiO}_{6}{ }^{20-22}$. The pure $\mathrm{B}_{2} \mathrm{O}_{3}$ glass mainly contains boroxol ring $\mathrm{B}_{3} \mathrm{O}_{9 / 2}$ with a trigonal $\mathrm{BO}_{3}$ unit. When $\mathrm{Bi}_{2} \mathrm{O}_{3}$ is added, $\mathrm{BO}_{3}$ units will be converted into $\mathrm{BO}_{4}$ structural units ${ }^{22}$. According to Bishay and Maghrabi ${ }^{23}$ bismuth oxide can take part in the structure of $\mathrm{Bi}_{2} \mathrm{O}-\mathrm{B}_{2} \mathrm{O}_{3}$ glasses in three different ways: (i) forming four coordinated boron atoms by giving its oxygen, (ii) forming $\mathrm{BiO}_{3}$ units of pyramidal point group $C_{3 v}$, and (iii) creates some non-bridging oxygen atoms. 
The vibrations of various borate units in the glass matrix can be studied with the appearance of absorption peaks between 700 and $1550 \mathrm{~cm}^{-1}$. The bands around $470 \mathrm{~cm}^{-1}$ are due to doubly degenerate bending vibrations of $\left[\mathrm{BiO}_{6}\right]$ units. The bands around $720 \mathrm{~cm}^{-1}$ are due to $\mathrm{B}-\mathrm{O}-\mathrm{B}$ bending vibrations in $\left[\mathrm{BO}_{3}\right]$ triangles. The characteristic $\mathrm{Bi}-\mathrm{O}$ stretching vibrations of $\mathrm{BiO}_{3}$ units correspond to bands around $840 \mathrm{~cm}^{-1}$. As no such bands are observed, it can be concluded that $\mathrm{BiO}_{6}$ units could outnumber $\mathrm{BiO}_{3}$ units in the glass network ${ }^{20}$. The bands around $1250 \mathrm{~cm}^{-1}$ in these glass samples are due to the formation of $\mathrm{Bi}-\mathrm{O}-$ of $\left[\mathrm{BiO}_{6}\right]$ groups. The infrared band in the range $1170-1260 \mathrm{~cm}^{-1}$ can be attributed to the $\mathrm{Bi}-\mathrm{O}-\mathrm{Bi}$ vibrations of $\left[\mathrm{BiO}_{6}\right]$ octahedral units. The presence of bands between 880 and $920 \mathrm{~cm}^{-1}$ are evidence for existence of $\left[\mathrm{BiO}_{6}\right]$ octahedral units in the glass samples. Hence, in present $x \mathrm{Li}_{2} \mathrm{O} \cdot x \mathrm{Na}_{2} \mathrm{O}$ $\cdot x \mathrm{~K}_{2} \mathrm{O} \cdot(50-3 x) \mathrm{Bi}_{2} \mathrm{O}_{3} \cdot 50 \mathrm{~B}_{2} \mathrm{O}_{3}$ glass system, IR bands between 460 and $520 \mathrm{~cm}^{-1}$ indicate coexistence of $\mathrm{BiO}_{3}$ and $\mathrm{BiO}_{6}$ groups ${ }^{4,24}$.

The $\mathrm{BB}$ series glasses also contain varied types like tri, tetra and penta borate groups. Stretching vibrations of $\mathrm{B}-\varnothing$ bonds in $\mathrm{B} \varnothing_{4}$ units $(\varnothing=$ oxygen atom bridging two boron atoms) from tri, tetra and penta borate groups corresponds to $\sim 950-980 \mathrm{~cm}^{-1}$ band positions. $\mathrm{B}-\mathrm{O}$ stretching vibrations of trigonal $\mathrm{BO}_{3}$ units corresponds to $1176-1500 \mathrm{~cm}^{-1}$ while bands $\sim 1320-1470 \mathrm{~cm}^{-1}$ signifies $\mathrm{B}-\mathrm{O}$ symmetric stretching vibrations of varied borate groups in $\mathrm{BO}_{3}$ units $^{25}$. The increased alkali oxide content played a role in broadening IR bands.

Infrared investigations on present glass systems reveal no significant changes in the overall structure of the glasses with composition. These glasses contained $\mathrm{BO}_{3}$ and $\mathrm{BO}_{4}$ units of varies types such as di, tetra, penta and ortho borates groups.

\section{CONCLUSIONS}

The characteristic boroxol ring $\left(806 \mathrm{~cm}^{-1}\right)$ was not observed in the present glass samples. The lead glass samples (LP and HP glasses) contained triangular and tetrahedral $\left(\mathrm{BO}_{3}\right.$ and $\left.\mathrm{BO}_{4}\right)$ groups along with $\mathrm{Pb}-\mathrm{O}$ vibrations. In the bismuth borate glass samples (BB glasses) bands around $1250 \mathrm{~cm}^{-1}$ confirmed the existence of $\mathrm{Bi}-\mathrm{O}-\mathrm{Bi}$ vibrations of $\left[\mathrm{BiO}_{6}\right]$ octahedral units. The IR bands between 460 and $520 \mathrm{~cm}^{-1}$ in $\mathrm{BB}$ glasses indicates the coexistence of $\mathrm{BiO}_{3}$ and $\mathrm{BiO}_{6}$ groups. The low lead content LP glasses contained more $\mathrm{BO}_{3}$ structural units than that of $\mathrm{BO}_{4}$ units signifying the action of $\mathrm{PbO}$ as glass network modifier. Whereas in high $\mathrm{PbO}$ content $\mathrm{HP}$ glasses conversion of $\mathrm{BO}_{3}$ structural units into $\mathrm{BO}_{4}$ units took place and hence $\mathrm{PbO}$ acted as network former. As most of the band positions remained the same in the infrared spectra, it can be concluded that the structure of the glasses is stable and the impact of variation of composition on the structure is not much significant.

Acknowledgements: The authors express thanks to the Head, Department of Physics, Osmania University for extending experimental facilities. One of the authors, Dr G. Ramadevudu thanks CSIR, New Delhi for providing financial assistance in the form of Research Associateship.

\section{REFERENCES}

1. Rajyasree Ch, Krishna Rao D (2011) Spectroscopic investigations on alkali earth bismuth borate glasses doped with CuO. J Non Cryst Solid 357, 836-41.

2. Cheng Y, Xiao H, Guo W, Guo W (2007) Structure and crystallization kinetics of $\mathrm{PbO}-\mathrm{B}_{2} \mathrm{O}_{3}$ glasses. Ceram Int 33, 1341-7.

3. ElBatal HA, Abdelghany AM, Ali IS (2012) Optical and FTIR studies of $\mathrm{CuO}$-doped lead borate glasses and effect of gamma irradiation. J Non Cryst Solid 358, $820-5$.

4. ElBatal FH, Marzouk MA, Abdel ghany AM (2011) Gamma rays interaction with bismuth borate glasses doped by transition metal ions. J Mater Sci 46, 5140-52.

5. Pal I, Agarwal A, Sanghi S (2012) Spectral analysis and structure of $\mathrm{Cu}^{2+}$-doped cadmium bismuth borate glasses. Indian J Pure Appl Phys 50, 237-44.

6. Ardelean I, Timar V (2008) Structural investigation of $\mathrm{MnO}-\mathrm{B}_{2} \mathrm{O}_{3}-\mathrm{PbO}-\mathrm{Ag}_{2} \mathrm{O}$ glass system by EPR spectroscopy. J Optoelectronics Adv Mater 10, 246-50.

7. Abdelghany AM, ElBatal HA, Marei LK (2012) Optical and shielding behavior studies of vanadium-doped lead borate glasses. Radiat Eff Defect Solid 167, 49-58.

8. El-Shaarawy MG, El-Batal FH (2002) Electrical conduction in $\mathrm{Bi}_{2} \mathrm{O}_{3}-\mathrm{B}_{2} \mathrm{O}_{3}$ glassy systems. Phys Chem Glasses 43, 247-53.

9. Saddeek YB, Shaaban ER, Moustafa ES, Moustafa HM (2008) Spectroscopic properties, electronic polarizability, and optical basicity of $\mathrm{Bi}_{2} \mathrm{O}_{3}-\mathrm{Li}_{2} \mathrm{O}-\mathrm{B}_{2} \mathrm{O}_{3}$ glasses. Phys B Condens Matter 403, 2399-407.

10. El Batal FHA, Nada N, Desouky SM, Khalil MMI (2004) Absorption and infrared spectra of gamma irradiated ternary silicate glasses containing cobalt. Indian J Pure Appl Phys 42, 711-21.

11. Abou Shama AA, El-Batal FH (2006) Structural analysis of glassy lead borate containing $\mathrm{MoO}_{3}$ in relation to its optical properties. Egypt J Solid 29, 49-67.

12. El-Kheshen AA, El-Batal FH, Marzouk SY (2008) UVvisible, infrared and Raman spectroscopic and thermal studies of tungsten doped lead borate glasses and the effect of ionizing gamma irradiation. Indian $J$ Pure Appl Phys 46, 225-38.

13. Motke SG, Yawale SP, Yawale SS (2002) Infrared 
spectra of zinc doped lead borate glasses. Bull Mater Sci 25, 75-8.

14. Ramadevudu G, Lakshmi Srinivasa Rao S, Shareeffuddin Md, Narasimha Chary M, Lakshmipathi Rao M (2012) FTIR and optical absorption studies of new magnesium lead borate glasses. Global J Sci Frontier Res Phys Space Sci 12, 41-6.

15. Kamitsos EI, Patsis AP, Karakassides MA, Chryssikos GD (1990) Infrared reflectance spectra of lithium borate glasses. J Non Cryst Solid 126, 52-67.

16. Ardelean I, Cora S, Rusu D (2008) EPR and FTIR spectroscopic studies of $\mathrm{Bi}_{2} \mathrm{O}_{3}-\mathrm{B}_{2} \mathrm{O}_{3}-\mathrm{CuO}$ glasses. Phys B Condens Matter 403, 3682-5.

17. Singh D, Singh K, Singh G, Manupriya, Mohan S, Arora M, Sharma G (2008) Optical and structural properties of $\mathrm{ZnO}-\mathrm{PbO}-\mathrm{B}_{2} \mathrm{O}_{3}$ and $\mathrm{ZnO}-\mathrm{PbO}-\mathrm{B}_{2} \mathrm{O}_{3}-$ $\mathrm{SiO}_{2}$ glasses. J Phys Condens Matter 20, 1-6.

18. Ghoneim NA, ElBatal HA, Abdelghany AM, Ali IS (2011) Shielding behavior of $\mathrm{V}_{2} \mathrm{O}_{5}$ doped lead borate glasses towards gamma irradiation. J Alloy Comp 509, 6913-9.

19. ElBatal HA, Abdelghany AM, ElBatal FH, EzzElDin FM (2012) Gamma rays interactions with $\mathrm{WO}_{3}$-doped lead borate glasses. Mater Chem Phys, 134, 542-8.

20. Ardelean I, Cora S, Lucacel RC, Hulpus O (2005) EPR and FT-IR spectroscopic studies of $\mathrm{B}_{2} \mathrm{O}_{3}-\mathrm{Bi}_{2} \mathrm{O}_{3}-\mathrm{MnO}$ glasses. Solid State Sci 7, 1438-42.

21. Dimitriev Y, Mihailova V (1992) Infrared spectral investigation of bismuthate glasses. In: Proceedings of the 16th International Congress on Glass, Madrid, vol 3, pp 293-8.

22. Doweidar H, Saddeek YB (2009) FTIR and ultrasonic investigations on modified bismuth borate glasses. J Non Cryst Solid 355, 348-54.

23. Bishay A, Maghrabi C (1969) Properties of bismuth glasses in relation to structure. Phys Chem Glasses 10, $1-11$.

24. Zheng H, Xu R, Mackenzie JD (1989) Glass formation and glass structure of $\mathrm{BiO}_{1.5}-\mathrm{CuO}-\mathrm{Ca}_{0.5} \mathrm{Sr}_{0.5} \mathrm{O}$ system. $J$ Mater Res 4, 911-5.

25. Pisarski WA, Pisarska J, Dominiak-Dzik G, RybaRomanowski W (2004) Visible and infrared spectroscopy of $\mathrm{Pr}^{3+}$ and $\mathrm{Tm}^{3+}$ ions in lead borate glasses. J Phys Condens Matter 16, 6171-84. 